\title{
Anthós
}

8-3-2017

\section{Interpreting Lincoln: Propaganda Myths in Film}

Jared Jensen

Portland State University

Follow this and additional works at: https://pdxscholar.library.pdx.edu/anthos

Part of the Film and Media Studies Commons

Let us know how access to this document benefits you.

\section{Recommended Citation}

Jensen, Jared (2017) "Interpreting Lincoln: Propaganda Myths in Film," Anthós: Vol. 8: Iss. 1, Article 4. https://doi.org/10.15760/anthos.2017.34

This open access Article is distributed under the terms of the Creative Commons Attribution-NonCommercialShareAlike 4.0 International License (CC BY-NC-SA 4.0). All documents in PDXScholar should meet accessibility standards. If we can make this document more accessible to you, contact our team. 


\section{Interpreting Lincoln:}

\section{Propaganda Myths In Film}

Jared T. Jensen

Lincoln's life was replete with the trappings of myth, much of which was to be grist for the Hollywood mill. From an impoverished background, he rose through law practice and one term in Congress to the presidency at a time of America's greatest crisis. He preserved the Union by presiding over the North's victory in the Civil War. He exemplified magnanimity, aiming to restore the South to the Union without vindictiveness. He emancipated the slaves, thereby redressing the most shameful blemish on American democracy. Finally, as though himself atoning for all the bloodshed in the four years of the Civil War, he died at the moment of victory. Poor boy made good. Ultimate American success story. Saviour. Emancipator. Deliverer. Unifier. Lincoln is America's own Christ-like hero, actually assassinated on Good Friday. It is all the stuff of myth, enshrined on screen as early as 1915 in D.W. Griffith's The Birth of The Nation (Coyne, 2008, pp. 41-42).

\section{Propaganda Myths}

It is likely that more has been written about Abraham Lincoln than any other political figure in U.S. history, and Coyne's (2008) depiction of Lincoln's life and lineage provides insight into why that is the case. Though there is significant debate among scholars about many of Lincoln's moral and political positions, perspectives that break with the common mythology of an almost flawless Lincoln are 
often relegated to academic bookshelves, rarely making their way into popular culture. This leaves the public exposed to a version of history, and a version of reality, that only glorifies its former leader. Popular reconstructions of Lincoln stealthily encourage the adoption of a particular American political ideology, and the public is meant to quietly adopt the presented narrative rather than account for conflicting ideas when considering its own history. This is important, particularly when historical atrocities are discussed. It is much easier to focus on the greatness of a leader than it is to confront the peccancy of slavery, or the likelihood that Lincoln was flawed and not immune to racist beliefs. That said, I am not interested in providing a perspective that describes Lincoln as good or bad. Nor am I interested in making arguments about states' rights or Lincoln's effectiveness as a leader. What I'll focus on here is the importance of how reality is constructed through propaganda, and that when politicians are mythologized history is inevitably distorted and mischaracterized. This argument contributes to a larger discussion within the mass communication discipline as it relates to propaganda, organized myth, and hyperreal representations of historical figures (Baudrillard, 1994; Ellul, 1965; Soules, 2015). Although Coyne (2008) doesn't directly describe it as propaganda, his comments allude to the idea that Hollywood's depictions of Lincoln exemplify cultural myth and paint the President as a savior, sometimes even using religious allusions to Christ as a way of buoying the myth's effectiveness.

In order to demonstrate this, I must first define what I mean by propaganda which is complex, often subtle, and multifaceted. I draw upon the works of Ellul (1965) and Soules (2015) who both write 
extensively about propaganda detailing the characteristics, categories, and social effects that one can relate it to. In its simplest form, we can define propaganda as an act of communication that is manipulative in nature, one that seeks to win the compliant mobilization of a mass audience. The propagandist is interested in promoting a value system that inspires his audience toward action, or even inaction, depending on his aims. In this case, myths of Lincoln inspire the viewer to think of American democracy as a system that upholds justice, truth, integrity, and is replete with glory. Furthermore, propaganda itself contributes to Ellul's (1965) notion of an organized myth. In this context, myth is a declared notion of beliefs based in fantasy, possibly even hyperbole, that are imposed and/or reinforced by the propagandist, and are meant to "respond to a group of already established tendencies or attitudes" (p. 36). Taken together, propaganda myths are, at least in part, communications of support for a larger, powerful story, delusions that are meant to blur the truth and deviate from fact.

Perpetual propaganda myths about Lincoln constitute a new version of the man. Thus, a hyperreal (Baudrillard, 1994) version of Lincoln is created and disseminated throughout the public consciousness. What was real is blended with fiction and the boundaries of the actual are blurred. Baudrillard defined hyperreality as a sign without an original referent, and argued that Americans reconstruct imitations of themselves that are more real than the original. Modern celebrity is an excellent example of this imitation celebrities create hyperreal versions of themselves that are presented to the public. Eco (1986) posits that hyperreal signs seek to replace 
and abolish the distinction of the reference. Simply put, the fictitious Lincoln has become truer. He is the Lincoln that modern society knows and is aware of, and every time he is depicted in dramatic fashion he is reconstructed, and thus distanced from the man who actually existed. Morris (1988) writes that the true "begins to be reproduced in the image of the pseudo, which begins to become the true" (p. 6). This consistent reproduction not only pulls what was real into ever-changing examples of new hyperreal truths, but an expectation of support for the new reality is thrust onto the viewer, which in turn plays into the propagandist's goal of a compliant audience.

\section{Lincoln as Myth}

As with many leaders throughout history, mythic tales have become ubiquitous with representations of Lincoln. Stokes (2011) argues that Lincoln was mythologized in the early part of the 20th Century through a variety of organized constructions in popular culture, positioning him as a "political symbol of sectional reconciliation and national unity" (p. 207). In his book, Lincoln Legends, Steers (2007) tackles pervasive cultural tales surrounding the former President, many of which exhibit the abandonment of one reality as it morphs into another. For example, stories of Lincoln's boyhood walk to school were doubled at some point, from two miles to four. Similarly, Lincoln made an acre-long fence when he was a young man, but retellings of the incident expanded the fence to a hectacre. Over time, Lincoln was re-imagined in American culture as a man with Herculean strength, one who was strong enough to 
encounter and manage suicidal depression, and honest without fault. He was fictionalized in a tale of The Gettysburg Address, written by Mary Raymond Shipman Andrews (1908) in the early part of the 20th century. Andrews' tale was a complete fabrication, but it was nonetheless popularized and subsequently taught to schoolchildren in almost every school in the nation (Steers, 2007).

Many myths of Lincoln are also easily associated with America's rags-to-riches fantasy, the notion that anyone can pull themselves up by their bootstraps and become powerful. His birthplace, a meager log cabin, rests in Illinois, and is housed in what Steers (2007) describes as something akin to a Greek temple built in honor of a fallen God. The idea that a building so opulent was constructed to surround another lesser, more humble building, is an excellent example of the symbolic myth that can become linked to an actual place. Symbols of Lincoln's meager beginnings and subsequent rise to the presidency are meant to inspire audiences toward buying into the rags-to-riches fantasy. The birthplace itself departs from reality and becomes myth when we consider the fact that it is simply Lincoln's traditional birthplace, that the log cabin has been literally disassembled and reassembled so many times over the years, that what now exists is merely a symbol, not the actual thing. Dwight Pitcaithley, a former historian for the National Park Service argued that the $\log$ cabin memorial represents a "symbolic need for an accessible past and a willingness to embrace myths that are too popular, too powerful, to be diminished by the truth" (as cited in Steers, 2007, p. 13). It is through this presentation of the log cabin that we begin to see truth conceptualized as something that can 
diminish myth, and Pitcaithley's comments would lead us to believe that embracing myth is more important than considering truth. Never mind that attempting to hold both myth and truth at once may be preferable if one is seeking an educated population.

These reconstructions of the man lay the foundation for Lincoln becoming a tool of propaganda as they all solicit emotional responses from the audience in order to attain adoption of American ideology. Ellul (1965) describes ideology as "any set of ideas accepted by individuals or peoples, without attention to their origin or value" (p. 116). He goes on to describe the importance of myth in relation to ideology, arguing that myth requires emotion; it is deeper, more of a sacred feeling than ideology. In Ellul's view, Happiness, Progress, and Work are myths - ideologies are systems, such as Democracy or Socialism. Myths inspire support for prevailing ideologies. The Lincoln myths specifically seek to provide reinforcement for the notion that America is a grand nation, simultaneously individualist and unified. The myths work with each other throughout the culture, urging people "to adopt a mystical attitude" (p. 11), permeating many levels of consciousness. As is exemplified by the Lincoln log cabin, these myths are taken apart and reconstructed so many times that the truth becomes elusive, and almost inaccessible. It is at this point that the truth may derive less relevance in the construction of reality than the myth, and in my view, nowhere is this more apparent than in films that extol Lincoln. 


\section{Griffith's Lincoln}

Consider D.W. Griffith's (1930) Abraham Lincoln, which was the first biographical sound film (talkie) ever attempted. Although Griffith is now thought to be one of the most influential filmmakers in history due to his technological contributions to the film industry, his moral contributions were sordid (Merritt, 2000). Examples of support for white supremacy are littered throughout his most successful film, Birth of a Nation (Griffith, 1915). Hearts of The World (Griffith, 1918), a propaganda film funded by the British government, was a

direct attempt to garner support from the American public to join the World War I effort (Lennig, 2011). But while Hearts of The World (Griffith, 1918) was attempting to sell a war, Abraham Lincoln (Griffith, 1930) was attempting to sell the myth of a man and garner further adoration for the Lincoln story.

Walter Huston stars as the film's hero, and plays the President as humane and compassionate. Dialogue in the film is slow and prodding, seemingly outdated, highlighting a lack of sophistication compared to that of modern scripts. However, the values that Griffith is attempting to associate with the President are clear: Lincoln is a man of contrast. He is compassionate when he pardons unjustly convicted soldiers, and weeps after signing a proclamation for 75,000 volunteers needed for The Civil War; yet he is also strong and stalwart, exhibiting feats of strength, rolling a beer-barrel over his legs to take a drink, and getting into scuffles with others as a young man. Lincoln's intellect is shown to be eminently effective in war, and charming in love. Ann Rutledge, Lincoln's first love interest, seems predisposed to Lincoln's linguistic charms, which inspires her 
adoration. The famous Lincoln-Douglas Debates are abbreviated to a short back-and-forth composed of stilted dialogue, ending with a forceful Lincoln proclaiming his rejection of state secession and support for the abolishment of slavery. All of these moments culminate to Lincoln's dramatic assassination at the hands of John Wilkes Booth.

Immediately after Lincoln's death, the viewer is taken back to his birthplace as the film cuts to a shot of a long forest where a model of the Lincoln $\log$ cabin rests. It is humble, small, empty, and unassuming. The Battle Hymn of The Republic, a musical theme used in several films about Lincoln (Coyne, 2008), swells as the viewer is transported once again to another model - a reconstruction of The Lincoln Memorial. The camera slowly zooms in on the structure, and an angelic glow begins to appear as a backdrop, eventually bathing the statue of a seated Lincoln in white light. Without the need for language, Griffith takes us from death, to birth, to legend in the span of about two minutes.

\section{Spielberg's Lincoln}

Eighty-two years later, the myth of Lincoln was revisited by one of the most powerful and popular contemporary filmmakers in Hollywood, Stephen Spielberg. Much like Griffith, subtlety is not likely an adjective that would be used to describe Spielberg's work. His considerable canon spans many genres, including science fiction and adventure, but he also helms works of historical drama, tackling events of significance such as the Holocaust, the slave trade, and the 
harsh reality of battle in World War I (Derry, 2000). His work is highly dramatic and emotionally evocative, attempting to hook the viewer through a variety of emotional and empathetic pleas. Lincoln (King, Lupi, Skoll, \& Spielberg, 2012) is no exception. Spielberg's Lincoln is portrayed as emotional, calculated, and mysterious. He ambles through battlefields, humbled by the deaths of piles of soldiers, while exhibiting an intellectual peace that endures throughout. Promotional posters for the film even depict Lincoln with his head tilted forward, gazing down thoughtfully, hinting at Rodin's (1880) infamous statue, The Thinker.

In contrast to Griffith's (1930) film, Lincoln (King, et al., 2012) presents a more sophisticated rendition of Lincoln and history. Based on the book, Team of Rivals: The Political Genius of Abraham Lincoln (Goodwin, 2005), Lincoln (King, et. al., 2012) tells the story of the political rhetoric and controversy between the President, his cabinet, and the House of Representatives in the lead up to the passage of the 13th Amendment which abolished slavery in the United States. By virtue of its title, Lincoln is centralized and framed as the primary figure in the political move to end slavery, which serves to reinforce his cultural distinction as 'the great emancipator'. Part of the appeal of Goodwin's (2005) Team of Rivals is that Lincoln surrounded himself with his challengers in order garner sound, thoughtful advice. But while many characters in the film do challenge the President, others, particularly the African-American servants and military personnel, provide support for the 'great emancipator' distinction through displays of deference. In the opening scene, white and black military men recite the Emancipation Proclamation to 
Lincoln (King, et. al., 2012). Though he mildly deflects these displays of overt praise, Lincoln also seems to quietly accept his role as emancipator and champion. In one of the films final scenes, an African American servant hands Lincoln his gloves, and without words, affectionately and dramatically observes the President leaving the White House, toward his ultimate death and assassination.

Framing Lincoln as the emancipator lays the foundation for Spielberg to begin to make use of Christianity as way of connecting Lincoln to the savior archetype, the "Christ-like hero" that Coyne (2008) posits as an integral part of the Lincoln mythos. Spielberg's Lincoln uses God as a rhetorical device in public address. On the day of his death, Good Friday, Lincoln expresses a desire to visit Jerusalem and walk in the footsteps of David and Solomon (King, et. al., 2012). In the film's dramatic final scene, a deceased Lincoln lay on his deathbed while the camera pans toward the flame of a candle that rests on a nearby tabletop. Slowly, Lincoln appears within the flame, and the scene fades into a flashback of Lincoln delivering his second inaugural address. For the first time in the film, chronology is abandoned, and the viewer is ushered back in time. Spielberg's use of this transportation as a narrative device negates the finality of Lincoln's death, which can be seen as akin to the resurrection of Christ. Christ dies for the sins of the people and rises three days later, a metaphor suggesting that not only is he a savior but that his message lives on, and cannot be stifled by death. This too seems to be Spielberg's take on Lincoln. There is afterlife. There is magic surrounding Lincoln. The film, by virtue of its existence, is already a hyperreal reconstruction of the President, but the choice to portray 
Lincoln's death, and then immediately revisit his life, provides an opportunity for the filmmakers to induce an even deeper mystical attitude for the viewer. For it is through these allusions to

Christ that the audience is pulled into the magical narrative of Lincoln as a savior.

\section{Discussion}

The propagation of Lincoln as a savior archetype is a problematic disregard for historical controversy. For instance, there is strong evidence that Lincoln struggled with his religious beliefs throughout his life, and that at one time, may have even identified as an atheist (Mansfield, 2012). But Spielberg elects to portray Lincoln as a man of faith whose dying wish is to visit Jerusalem. Furthermore, his focus on the 13th Amendment disregards the possibility that Lincoln's original political plan was to eliminate slavery gradually and send newly freed slaves back to Africa (Bennet, 1999). Evidence for this perspective is shown in the Lincoln-Douglas Debates of 1858, which were severely abridged in Griffith's (1930) film. At the actual debates, Lincoln rejected the abolitionist movement, and claimed that he was not "in favor of bringing about in any way the social and political equality of the white and black races" (Lincoln \& Douglas, 1858). It is also widely acknowledged that Lincoln used racial expletives in his private life to refer to African-Americans from time to time (Bennet, 1999), which Spielberg and Griffith chose not include in Lincoln's vernacular. Perhaps Lincoln changed his mind about racial equality when he became president. Perhaps he was merely a politician who said one thing to garner public support, but 
believed another. Nevertheless, these films, these reconstructions of Lincoln only show certain sides of the man, which inherently removes nuance and subtlety.

The problem is that nuance and subtlety are important when considering historical events, but easily abandoned in the creation of propaganda. Soules (2015) argues that propagandists believe that the public "need wise leaders touched with gold to show that the state's political interests are aligned with universal principles of justice, goodness and truth" (p. 130). Both Spielberg and Griffith present a man that is "touched with gold", an orchestrator of emancipation. Both films contain subtle and overt resemblances to the notion of Lincoln as Christ-like. Both films, to some extent, contribute to historical delusion, and one-sided portrayals of history. Both films are examples of Ellul's (1965) concept of an organized myth that taps into viewer's emotions, meant to inspire states of emotional appreciation and connection to the Lincoln narrative. Both films, by virtue of their existence, are history, but they are also constructing a hyperreal history, and presenting events that motivate viewers toward further allegiance to the Lincoln mythos, American history, and therefore America's system of government.

\section{Conclusion}

Part of the argument that I present is that the fictitious Lincoln, the hyperreal Lincoln, has become truer in the public sphere than the man who actually lived, and that his lineage is now widely informed through film. Although each film I analyze differs in tone, they both illustrate that the mythic Lincoln is the primary Lincoln 
communicated to the public. The fact that the Spielberg and Griffith films were released 82 years apart from each other shows the significant salience that the Lincoln mythos have achieved, but the nuance with which the actual Abraham Lincoln lived, and conducted himself, becomes lost in the reconstruction of a mythic character. The implication is that when fictitious, savior-oriented depictions of Lincoln are presented to the public, they are contributing to Ellul's (1965) notion of an organized myth: the encouragement of the adoption of a mystical attitude in regards to history and American political ideology. My analysis contributes to a wider theoretical discussion regarding propaganda, organized myth, and hyperreal presentations of historical figures. The example of Lincoln as myth provides specific insight into how the three concepts are connected, and why they are important to consider when consuming cultural political narratives. For it is through popular dissemination, through mainstream film in particular, that these sorts of myths reconstruct history through the eyes and biases of individual filmmakers; these myths that can be diminished by truth. Painting Lincoln as a savior archetype and mingling his life with Christ-like connotation is likely intended as a form of tribute, but the inherent result is a less informed public that lacks the knowledge of a flawed, complex historical figure.

\section{References}

Andrews, M. (1908). The perfect tribute. New York: Scribner.

Baudrillard, J. (1988). America. London: Verso. 
Bennet, L. (2000). Forced Into Glory: Abraham Lincoln's white dream. Chicago: Johnson Pub. Co.

Coyne, M. (2006). Hollywood goes to Washington. London: Reaction Books LTD.

Derry, C. (2000). Stephen Spielberg. In Pendergast, T. \& Pendergast, S. (4th Edition) The International Dictionary of Films and Filmmakers- 2: Directors (pp.943-949). Chicago: St. James Press.

Eco, U. (1986). Travels in hyper reality: Essays. San Diego: Harcourt Brace Jovanovich.

Ellul, J. (1965). Propaganda: The formation of men's attitudes. New York: Random House.

Goodwin, D. (2005). Team of rivals: The political genius of Abraham Lincoln. New York: Simon \& Schuster

Griffith [Producer \& director]. (1915). Birth of a Nation [Motion picture]. United States: David W. Griffith Corp.

Griffith [Producer \& director]. (1918). Hearts of The World [Motion picture]. United States: D.W. Griffith Productions.

Griffith [Producer \& director]. (1930). Abraham Lincoln [Motion picture]. United States: D.W. Griffith Productions.

King, J., Lupi, D., Skoll, J. [Executive producers] \& Spielberg, S. [Director]. (2012). Lincoln [Motion picture]. United States: Dreamworks SKG.

Landsberg, A. (2015). 'This isn't usual, Mr. Pendleton, this is history': Spielberg's Lincoln and the production of historical knowledge. Rethinking History. 19:3. 482-492. DOI: 10.1080/13642529.2015.1006868. 
Lennig, A. (2011). Hearts of The World. Film History. 23:4. 428-458.

Lincoln, A. \& Douglas, S. (1858). The Lincoln-Douglas debates: 4th debate, part I. Teaching American History. Retrieved from http://teachingamerican history.org/library/document/thelincoln-douglas-debates-4th-debate- part i/

Mansfield, S. (2012). Lincoln's battle with God: A president's struggle with faith and what it meant for America. Nashville: Thomas Nelson.

Merritt, R. (2000). D.W. Griffith. In Pendergast, T. \& Pendergast, S. (4th Edition) The International Dictionary of Films and Filmmakers- 2: Directors (pp.399-403). Chicago: St. James Press.

Morris, Meaghan

(1988) At Henry Parkes Motel. Cultural Studies. 2:1. 1-47.

Rodin, A. (1880). The Thinker. Independent work. Musée Rodin, Paris.

Soules, M. (2015). Media, persuasion and propaganda. Edinburgh: Edinburgh University Press.

Steers, E. (2007). Lincoln legends: Myths, hoaxes and confabulations associated with our greatest president. Lexington, KY: University Press of Kentucky.

Stokes, M. (2011) Abraham Lincoln and the Movies. American Nineteenth Century History. 12:2. 203-231. DOI: $10.1080 / 14664658.2011 .594651$ 